\title{
New varieties of winter rye of intensive type
}

\author{
E.M. Esimbaeva, N.A. Petrovtseva*, and E.N. Pasynkova
}

Leningrad Research Institute of Agriculture Belogorka, 188338 Belogorka village, Gatchina district, Leningrad region, Russia

\begin{abstract}
The work of breeders of the Leningrad Research Institute of Agriculture Belogorka on the creation of new short-stature varieties of intensive type winter rye, characterized by increased resistance to adverse soil and climatic conditions of northern Europe is briefly described. The methods of selection used in the institute are presented, including the method of directed transpollination of crops "on a flower bed" developed in the winter rye laboratory. The characteristic of new varieties based on economic and useful features and on the main elements of the crop structure is given. It was shown that the new varieties significantly exceeded the standard Volkova variety in winter and lodging resistance, which allows obtaining a stable grain harvest even in unfavorable years. In addition, new varieties are characterized by the size and uniformity of seeds at the weight of 1000 grains $38-42 \mathrm{~g}$, practically not inferior in this indicator to tetraploid and hybrid varieties of winter rye, which are more demanding of cultivation conditions.
\end{abstract}

\section{Introduction}

Winter rye is an important agricultural crop in many countries - it is of a great food, fodder, technical value [1]. Among other grain crops, rye has the lowest requirements for soil fertility, fertilizers, herbicides, pesticides, which allows obtaining ecologically clean and cheap grain. Due to its high winter and drought resistance, low requirements for the cultivation intensity, rye is considered a low-risk crop, especially in areas with poor soils and adverse climatic conditions. Also, rye is known for its ability to grow on acidic soils due to tolerance to high concentrations of mobile forms of aluminum [2,3].

Currently, rye is cultivated mainly in Europe as a grain crop [1], a number of countries use it as green fodder for domestic $[4,5]$ and wild animals [6]. Due to its content with a number of valuable amino acids, the rye grain is a good additive to feed dairy and beef cattle, and with the use of certain feeding technologies - for poultry and its young growth $[7,8]$.

Rye, along with the grain of other grain crops, is of great interest for grain nutritionists, as it is a promising product in the person's healthy nutrition system [9]. Also, rye is known as a siderate, used both in monoculture and in a mixture with leguminous herbs [10-12]. In recent times, the interest in the use of winter rye as a raw material for biogas production is growing [13].

Germany is the world leader in the export of grain rye, widely using the heterosis effect with hybrid varieties. The potential yield of German hybrids reaches $100 \mathrm{~kg} / \mathrm{ha}$ [1], which contributes to their distribution in other countries. However, the experience shows that in the harsh climatic conditions of the northern Europe countries, German hybrids do not always meet expectations, and are inferior to local varieties, especially in adverse years $[14,15]$.

Therefore, for each country practicing winter rye seeding, it is necessary to have varieties of its own selection, most adapted to the conditions of a particular cultivation region.

The Leningrad Research Institute Belogorka has been engaged in winter rye breeding since the moment a seed production station was founded in 1934 by N.I. Vavilov in the village of Suida of the Leningrad region. Since then, famous scientists P.F. Medvedev, G.I. Popov, V.T. Vasko, K.P. Veselova, N.G. Pugach, G.S Popova and others created and introduced into production 13 varieties of this crop [16].

Nowadays, different regions of Russia cultivate breeding varieties of the Leningrad Research Institute Belogorka, such as Gatchinskaya, Kustovka, Suida, Ladoga, Hybrid 173, Yaroslavna, Volkhova, Bylina, Era, Slavia. Currently, the Institute has prepared for transfer to the State Commission for variety testing its new shortstature varieties of intensive type, called Eureka and Dana, obtained on the basis of dominant and recessive short-stature breeds.

\section{Materials and methods}

The varieties and forms of winter rye from the world VID collection are used as the starting material for breeding, as well as varieties and hybrids of local selection, as they are the most adapted to complex soil and climatic conditions of northern Europe.

The creation of new winter rye varieties by the Leningrad Research Institute of Agriculture Belogorka is based on classical breeding methods, such as the directed

Corresponding author: Petrovtseva-Natalya@rambler.ru 
crossing of different initial material followed by an individual family selection of the best phenotypes.

In the breeding process, the method of directed transpollination of selected plants before flowering ("flowerbed" method), developed in the Leningrad Research Institute of Agriculture by a group of employees of the winter rye laboratory under the leadership of G.I. Popov is widely used.
This method allows quickly fixing desirable features in offspring due to the possibility of the controlled crossing of whole groups of plants, which increases the breeding process efficiency.

Taking into account this method, the scheme of the winter rye selection process presented in Figure 1 was developed, which allows creating a new variety within 5-6 years.

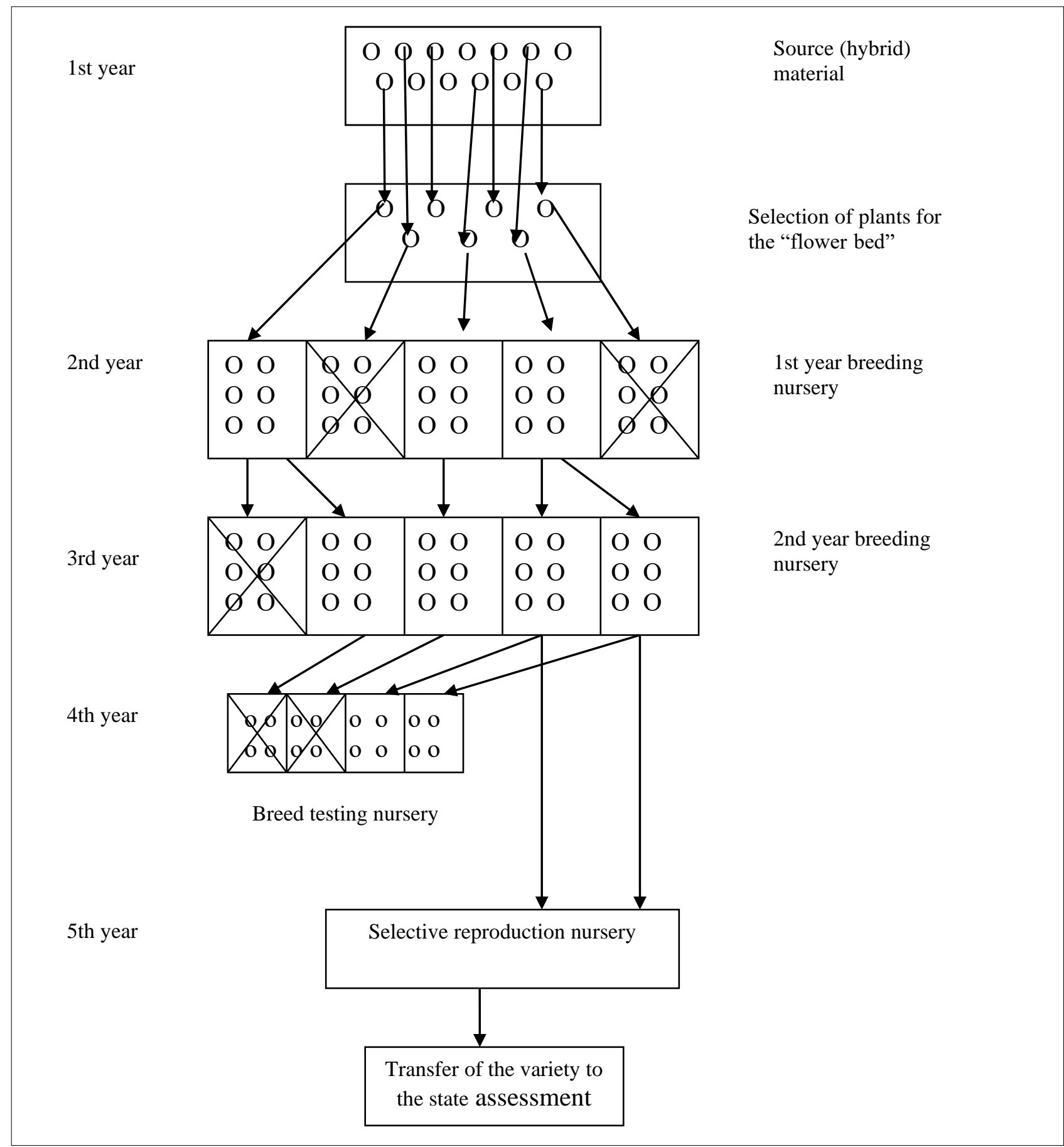

Fig. 1. Scheme of selection process of winter rye

The research is carried out in the Gatchinskiy district of the Leningrad region on experimental fields of the Federal State Budgetary Scientific Institution Leningrad Research Institute of Agriculture Belogorka. The used soil in the experimental fields is sod-podzolic, loamy, cultivated with a depth of the arable horizon of $20-25 \mathrm{~cm}$. The content of humus is $2.0-2.3 \%$, of salt extract $\mathrm{pH}$ is 5.2-5.5. Organic fertilizers are applied to the 
predecessor - early potatoes, in doses generally accepted for this crop, rye crops are fed once in spring during the renewal of vegetation with ammonia nitrate at a dose of $60 \mathrm{~kg}$ of active substance per hectare.

Hybrid nursery, breeding nurseries of the 1st and 2nd year, nursery tests of offspring are carried out manually on plots of $1-2 \mathrm{~m}^{2}$ in single or double repetition depending on the material quantity.

The competitive variety testing nursery (CVT), in which comparative evaluation of varieties is carried out, as well as breeding nurseries is laid in a mechanized way. The laying of nurseries is made according to the generally accepted method according to the recommendations of the All-Russian Institute of Crop Research (AICR) [17].

The evaluation of the obtained material is carried out according to the recommendations of the All-Russian Institute of Crop Research [18, 19], statistical processing of results is carried out according to Dospekhov B.A. [20]. Volkhova variety released in the North-West region of Russia is used as a standard for conducting this research.

\section{Results}

By 2011, based on Russian (Imerig, Valdai, Alpha, Volkhova, Bylina, Yaroslavna, Nadezhda, Saratovska 5, Saratovska 7, Antares) and Western European (EM-1, Jo-3364, Jo 7098, Hja 7043, Otello, SCW- 5994) varieties and forms of winter rye an extensive hybrid material based on dominant and recessive short-stature varieties was created. 20 best samples of this material were selected for seeding in "flowerbeds" for the purpose of directed transpollination. Female parent forms were presented by hybrids of the Bylina variety, used as a source of early ripeness. Male forms were presented by hybrids of the Volkhova variety with varieties such as Alpha, Antares, Saratovska 5, Saratovska 7, Nadezhda, Yaroslavna, Hja 7043, Otello. Over the next few years, the selection of short-stature forms with crop height of 90-110 cm and 110-130 cm according to the best economic and valuable features was carried out. As a result, by 2016 it was possible to obtain two short-stature populations, superior to the original varieties in a number of properties. These populations formed on the basis of two new varieties of mixed dominant recessive short-stature type - Eureka and Dana.

\section{Discussion}

The new varieties (Table 1) are characterized primarily by winter and lodging resistance, which ensures their stable yields even in the most adverse years. For example, in 2017, the amount of rainfall during harvest exceeded the average annual rate by two times, which contributed to the lodging of such varieties as Volkhova and Bylina, while varieties Dana and Eureka showed high resistance to lodging -8 and 9 points, and yield increase relative to the Volkhova standard $-37.5 \%$ and $28.1 \%$, respectively. In the same in 2017 due to the continued heavy rainfall in the autumn period, the departure of equipment on the fields was almost impossible until the third decade of September, as a result of which the sowing was carried out two weeks later than the optimal terms, on September 20-24. This greatly affected the winter resistance of plants in the winter period of 2017-2018, but the varieties Eureka and Dana overwintered significantly better than other varieties - their winter resistance was estimated at 8 of 9 possible points and the yield increase relatively to the standard amounted to $45 \%$.

At the same time, the new varieties have good indicators on the crop structure elements: plant height does not exceed $125 \mathrm{~cm}$, plants have a spike length $(10-11 \mathrm{~cm})$ which is sufficient for a group of shortstature varieties with a high density of spikes (3.6-4.0 pieces per $1 \mathrm{~cm}$ of ear length) and large uniform grain with a mass of 1000 seeds 38-40 g (Tables 2, 3).

Table 1. Characteristics of winter rye varieties according to the main economic and useful features (according to competitive variety testing)

\begin{tabular}{|c|c|c|c|c|c|}
\hline 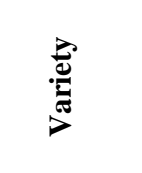 & 总 & 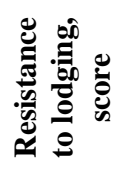 & 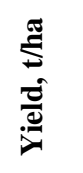 & 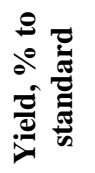 & 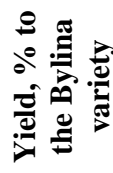 \\
\hline \multicolumn{6}{|c|}{2016} \\
\hline $\begin{array}{l}\text { Volkhova, } \\
\text { standard }\end{array}$ & 8 & 7 & 4.81 & - & +2.1 \\
\hline $\begin{array}{l}\text { Bylina } \\
\text { (parent) }\end{array}$ & 8 & 7 & 4.71 & -2.1 & - \\
\hline Eureka & 9 & 9 & 5.01 & +4.2 & +6.4 \\
\hline Dana & 9 & 8 & 4.86 & +1.0 & +3.2 \\
\hline \multicolumn{6}{|c|}{2017} \\
\hline $\begin{array}{l}\text { Volkhova, } \\
\text { standard }\end{array}$ & 8 & 5 & 3.60 & - & +5.0 \\
\hline $\begin{array}{c}\text { Bylina } \\
\text { (parent) }\end{array}$ & 8 & 5 & 3.43 & -4.7 & - \\
\hline Eureka & 9 & 9 & 4.61 & +28.1 & +34.4 \\
\hline Dana & 9 & 7 & 4.95 & +37.5 & +44.3 \\
\hline \multicolumn{6}{|c|}{2018} \\
\hline $\begin{array}{l}\text { Volkhova, } \\
\text { standard }\end{array}$ & 6 & 7 & 3.14 & - & -19.5 \\
\hline $\begin{array}{c}\text { Bylina } \\
\text { (parent) }\end{array}$ & 6 & 7 & 3.90 & +24.2 & - \\
\hline Eureka & 8 & 9 & 4.58 & +45.9 & +17.4 \\
\hline Dana & 8 & 8 & 4.56 & +45.2 & +16.9 \\
\hline
\end{tabular}

Table 2. Characteristics of winter rye varieties according to some elements of crop structure (averaged data)

\begin{tabular}{|c|c|c|c|c|}
\hline \multirow{2}{*}{ Features } & \multicolumn{4}{|c|}{ Variety } \\
\cline { 2 - 5 } & $\begin{array}{c}\text { Volkhova, } \\
\text { standard }\end{array}$ & Eureka & Dana & $\begin{array}{c}\text { Bylina } \\
\text { (parent) }\end{array}$ \\
\hline Plant height, cm & 118.9 & 102.5 & 123.0 & 136.5 \\
\hline $\begin{array}{c}\text { Productive stem } \\
\text { density, pcs./m }\end{array}$ & 163 & 196 & 205 & 176 \\
\hline Spike length, cm & 11.1 & 9.9 & 11.4 & 12.0 \\
\hline
\end{tabular}


Table 3. Characteristics of winter rye varieties according to some elements of crop structure (averaged data)

\begin{tabular}{|l|c|c|c|c|}
\hline \multirow{2}{*}{ Features } & \multicolumn{4}{|c|}{ Variety } \\
\cline { 2 - 5 } & $\begin{array}{c}\text { Volkhova } \\
\text { standard }\end{array}$ & Eureka & Dana & $\begin{array}{c}\text { Bylina } \\
\text { (parent) }\end{array}$ \\
\hline $\begin{array}{l}\text { The number of } \\
\text { spikelets in the spike, } \\
\text { pcs. }\end{array}$ & 37.8 & 39.6 & 40.2 & 38.4 \\
\hline $\begin{array}{l}\text { The number of } \\
\text { productive stems in } \\
\text { the plant, pcs }\end{array}$ & 5.5 & 5.3 & 5.4 & 4.8 \\
\hline $\begin{array}{l}\text { Grain weight of the } \\
\text { spike, g }\end{array}$ & 2.43 & 2.38 & 2.74 & 2.42 \\
\hline $\begin{array}{l}\text { The number of grains } \\
\text { in the spike, pcs. }\end{array}$ & 74 & 65 & 63 & 71 \\
\hline $\begin{array}{l}\text { Grain weight of the } \\
\text { plant, g }\end{array}$ & 8.54 & 8.25 & 8.43 & 7.5 \\
\hline $\begin{array}{l}\text { Weight of 1000 } \\
\text { grains, g }\end{array}$ & 35.0 & 38.0 & 40.0 & 37.0 \\
\hline
\end{tabular}

\section{Conclusion}

The method of directed transpollination of selected plants before flowering ("flowerbed" method) allows quickly fixing desirable features in offspring, which increases the breeding process efficiency. The new scheme of the winter rye selection process allowed creating new varieties within 6 years.

New varieties of winter rye Eureka and Dana are not inferior to the standard Volkhova variety in favourable years. At the same time, they have a high degree of adaptation to stressful conditions of growth and in adverse years exceed the yield of other varieties.

The new varieties significantly exceeded the standard Volkova variety in winter and lodging resistance, which allows obtaining a stable grain harvest in unfavourable years.

Also, new varieties are characterized by the size and uniformity of seeds at the weight of 1000 grains $38-42 \mathrm{~g}$, practically not inferior in this indicator to tetraploid and hybrid varieties of winter rye, which are more demanding of cultivation conditions.

Thus, the varieties Eureka and Dana can be considered as promising for cultivation in the northern regions of Europe with difficult soil-climatic conditions.

\section{References}

1. A.A. Goncharenko, Actual issues of winter rye selection (Moscow, 2014)

2. B.Y. Kim, A.C. Baier, D.J. Somers et al, Aluminum tolerance in triticale, wheat and rye, Euphytica, 120(3), 329-337 (2001)

3. F.L. Xiao, F.M. Jian, M. Hideaki, Aluminuminduced secretion of both citrate and malate in rye, Plant and Soil, 242(2), 235-243 (2002)

4. H. N. Phillips, B. J. Heins, K. Delate et al., Impact of grazing dairy steers on winter rye (Secale cereale) versus winter wheat (Triticum aestivum) and effects on meat quality, fatty acid and amino acid profiles, and consumer acceptability of organic beef, PloS ONE, 12(11), 1-18 (2017)

5. A.M. Kurnayev, K.M. Syrovatko, S.M. Kulik et al., Nutritional and productive performance of green material and silage of winter rye and typhon mix, Science bulletin of National University of biological resources and natural resources management of Ukraine, 205, 143-149 (2015)

6. H. K. K., T. J. B., C. K. Y. et al., A comparison of oak browse (Quercus spp.) and silages of rye and maize with respect to voluntary intake, digestibility, nitrogen balance and rumination time in penned korean sika deer, Animal Feed Sci. and Technol., 61(1-4), 351-359 (1996)

7. D. Boros, R.R. Marquardt, W. Guenter et al., Chick adaptation to diets based on milling fractions of rye varying in arabinoxylans content, Animal Feed Sci. and Technol., 101(1-4), 135-149 (2002)

8. M.R. Bedford, Mechanism of action and potential environmental benefits from the use of feed enzymes, Animal Feed Sci. and Technol., 53(2), 145-155 (1995)

9. D.N. Cooper, R.J. Martin, N.L. Keim, Does whole grain consumption alter gut microbiota and satiety? Healthcare, 3, 364-392 (2015)

10. S. Kuo, B. Huang, R. Bembenek, Effect of winter cover crops on soil nitrogen availability, corn yield, and nitrate leaching, The sci. world, 1(S2), 22-29 (2001)

11. A. Lawson, C. Cogger, A. Bary et al., Influence of seeding ratio, planting date and termination date on rye-hairy vetch cover crop mixture performance under organic management, PLoS ONE, 10(6), (2015)

12. R.W. Malone, J.F. Obrycki at al., Harvesting fertilized rye cover crop: simulated revenue, net energy and drainage nitrogen loss, Agricult. \& Environmental Letters, (2018)

13. J. Bondziewicz, J. Cebula, K. Piotrowski et al., Silage from the standard rye as substrate for the production of agricultural biogas, Science bulletin of National University of biological resources and natural resources management of Ukraine, 261, 2937 (2017)

14. M. Serenius, E. Huusela-Veistola, H. Avikainen et al., Effects of sowing time on pink snow mould, leaf rust and winter damage in winter rye varieties in Finland, Agricult. and Food Sci., 14, 362-376 (2005)

15. K. Hakala, K. Pahkala, Comparison of central and northern European winter rye cultivars grown at high latitudes, The J. of Agricult. Sci., 141(2), 169-178 (2003)

16. G.I. Popov, V.T. Vasko, N.G. Pugach, Winter rye selection (Leningrad, 1986)

17. Methods of state variety testing of agricultural crops (Kolos, Moscow, 1971) 
18. Guidelines for the study of winter rye collection (Leningrad, 1985)

19. International CMEA classifier of the Secale L specie (Leningrad, 1984)
20. B.A. Dospekhov, Field experiment methods (Kolos, Moscow, 1968) 